\title{
Morphology and Composite Characteristics of Lightweight Concrete with Styrofoam Filling Materials
}

\author{
$1^{\text {st }}$ Novizal $^{1}, 2^{\text {nd }}$ Joniwarta $^{2}, 3^{\text {rd }}$ Fauzi $^{3}, 4^{\text {th }}$ Mutia Anissa Marsya ${ }^{4}$ \\ \{novizal@dsn.ubharajaya.ac.id ${ }^{1}$, fauzi_pf07@yahoo.co.id ${ }^{2}$, jonoworto@gmail.com ${ }^{3}$, \\ mutianissya@gmail.com ${ }^{4}$ \} \\ University of Bhayangkara Jaya Raya, Indonesia ${ }^{1,2,3,4}$
}

\begin{abstract}
Concrete is made which is a material commonly used for construction and structures in buildings, concrete has many advantages compared to other building materials. However, concrete has one weakness, namely the specific gravity is high enough so that the dead load on a structure becomes large. Several methods can be used to reduce the concrete density, including using lightweight aggregates. One method to make lightweight concrete is by adding Styrofoam waste materials. However, this specific weight reduction is not followed by the addition of concrete compressive strength, so that until now lightweight concrete using Styrofoam is only used for nonstructural parts. For this purpose, it is made to find out how much the influence of Styrofoam as a substitute for coarse aggregate on Concrete with the additional percentage of Styrofoam by $0 \%, 15 \%$, and $35 \%$, and $50 \%$ of the weight of the Concrete mixture.
\end{abstract}

Keywords: Styrofoam, the weight of concrete volume, compressive strength, morphology

\section{Introduction}

Concrete is part of the development component in the field of construction, technological progress and the economic crisis that occurred in Indonesia, directing infrastructure development in the use of structures with lightweight materials[1]. But overall it does not have an impact on increasing the strength of the structure [2]. In the modern era shows the development of the use of the lightweight material as a structure-forming material will reduce the total weight of a building, thereby reducing the supporting parts and foundations such as in the construction of housing, offices, hospitals and so on.

The development of building construction at this time is influenced by the high global warming, resulting in issues that require, concrete manufacturing technology innovation to answer the challenges of need, including environmentally friendly, thus making construction experts compete in carrying the green building concept. One way to apply the concept of green building is to reuse used material or waste as building materials[3]. This will reduce costs and increase waste usage[4]. By using Styrofoam in the concrete mixture, the total weight of the concrete will be lighter and the use value of styrofoam will increase, but this will affect the strength of the concrete or along with the addition of styrofoam to the concrete mixture[5], [6].

Based on the above, this study aims to evaluate how much influence Styrofoam has in concrete mixtures. The characteristics in question are the morphology of the effect of the 
mixture with the ratio of styrofoam to the volume of concrete which varies from $0 \%, 15 \%$, $35 \%$, and $50 \%$, keeping it analyzed using SEM.

\section{Research methods}

\subsection{Research Flow Chart}

The experiments carried out in the laboratory with the implementation stages in the outline can be seen in the flowchart below, where the experimental steps are described in the form of Flowchart. The material is prepared for mixing by calculating the volume cocomposition of the concrete composition material in cubic by using a volume ratio of 1000 $\mathrm{kg} / \mathrm{m}^{3}$, taken from the basic composition of the concrete mix plan [7].

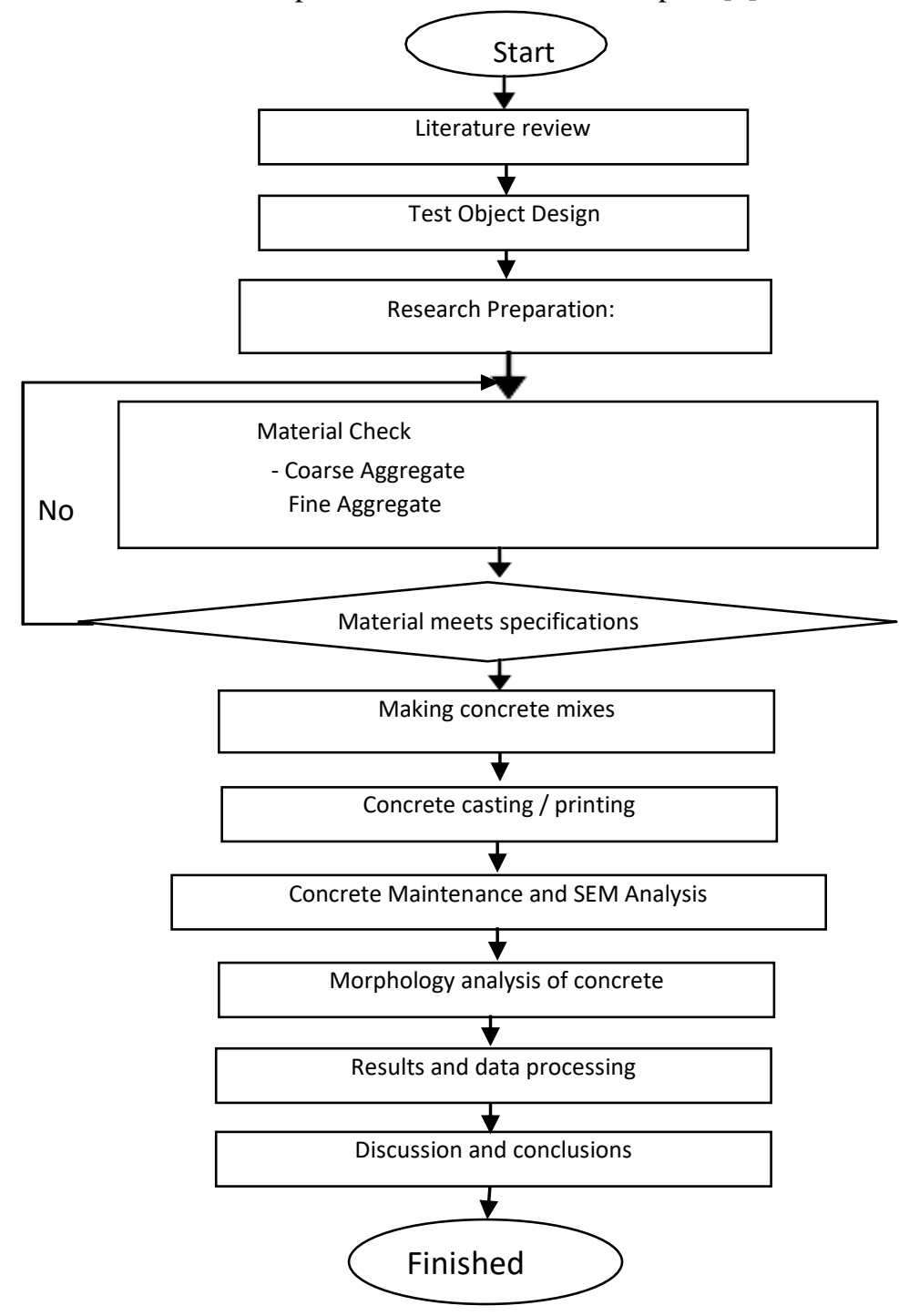

Fig 1. Research flow chart 
Table 1. Concrete material composition with a composition of weight $(\mathrm{kg})$

\begin{tabular}{cccccc}
\hline No & $\begin{array}{c}\text { Type of Material } \\
\text { Concrete }\end{array}$ & $\begin{array}{c}\text { Normal } \\
\text { concrete }\end{array}$ & $\begin{array}{c}\text { 15\% Styrofoam } \\
\text { Concrete }\end{array}$ & $\begin{array}{c}\text { Styrofoam } \\
\text { concrete } 35 \%\end{array}$ & $\begin{array}{c}50 \% \text { styrofoam } \\
\text { concrete }\end{array}$ \\
\hline 1 & Water $(\mathrm{kg})$ & 42,8 & 42,8 & 42,85 & 42,85 \\
2 & Cement $(\mathrm{kg})$ & 181,4 & 181,4 & 181,4 & 181,4 \\
3 & Sand $(\mathrm{kg})$ & 999,9 & 849,9 & 649,9 & 407,2 \\
4 & Gravel $(\mathrm{kg})$ & 257,3 & 218,5 & 167,1 & 61128 \\
5 & Styrofoam $(\mathrm{kg})$ & 0 & 2,87 & 6,6 & 9,5 \\
\hline
\end{tabular}

\section{Result and Discussions}

Based on the results of testing concrete construction materials obtained data that plays a good role in the calculation of the composition of concrete composers also for the calculation of hardness and pull of concrete In table 2. listed concrete construction materials that have been tested:

Table 2. Test data for concrete composite

\begin{tabular}{cccccc}
\hline \multirow{2}{*}{ Testing type } & \multicolumn{5}{c}{ Type of material } \\
& Cemen & Sand & gravel & Styrofoam & Water \\
\hline Specific gravity & 3,15 & 2,4 & 2,49 & 0,0236 & 1 \\
Volume weight & 1,27 & 1,4 & 1,8 & 0,0223 & 0,98 \\
\hline
\end{tabular}

Figure 4.1 Graph of aggregate aggregation gradations From the results of the combination of mixed materials for concrete production there is a combined gradation that gives effect to the strain value and the compressive strength of the concrete made. Material composition Concrete made for $1 \mathrm{~m} 3$ required the composition of materials arranged in a ratio of 1: 5:1 and 0 as shown in table 3[8][8][7][5][4][4][3].

Table 3. The composition of material requirements for a concrete mix for $1 \mathrm{~m}^{3}$

\begin{tabular}{cccccccc}
\hline $\begin{array}{c}\text { Comparison of } \\
\text { composition } \\
\text { Concrete mixture }\end{array}$ & \multicolumn{9}{c}{ Concrete Mixture Composition (kg) } & & Concrete \\
& Cement & Sand & Gravel & Styrofoam & Water & mass (kg) \\
\hline $1: 5.0: 1.0: 0$ & 181,42 & 999,99 & 257,13 & 0 & 42,85 & 1481,39 \\
$1: 4,25: 0,85: 0,90$ & 181,42 & 849,99 & 218,57 & 2,87 & 42,85 & 1295,7 \\
$1: 3,25: 0,65: 2,10$ & 181,42 & 649,99 & 167,15 & 6,69 & 42,85 & 1048,1 \\
$1: 2,50: 0,5: 3,00$ & 181,42 & 407,29 & 128,56 & 9,55 & 42,85 & 769,67 \\
\hline
\end{tabular}


Table 4. The composition of the mixture of concrete constituent materials $(\mathrm{kg})$

\begin{tabular}{cccccccc}
\hline $\begin{array}{c}\text { Comparison of } \\
\text { composition } \\
\text { Concrete mixture }\end{array}$ & Cemen & Sand & gravel & Styrofoam & Water & Concrete Mixture Composition (kg) \\
\hline $1: 5.0: 1.0: 0.0$ & 0,73 & 3,99 & 1,03 & 0 & 0,17 & 5,92 \\
$1: 4,25: 0,85: 0,90$ & 0,73 & 3,39 & 0,87 & 0,012 & 0,17 & 5,172 \\
$1: 3,25: 0,65: 2,10$ & 0,73 & 2,59 & 0,67 & 0,027 & 0,17 & 4,187 \\
$1: 2,50: 0,5: 3,00$ & 0,73 & 1,63 & 0,51 & 0,038 & 0,17 & 3,078 \\
\hline
\end{tabular}

To determine the needs of concrete constituent materials per piece of concrete made the concrete shape that we want, and has been done and made with the size of the building and composition with the data below: Dimensions of Concrete: $10 \times 10 \times 40 \mathrm{~cm}$ for Beams with a volume of $4000 \mathrm{~cm}^{3}$ is equivalent to $0.004 \mathrm{~m}^{3}$. For making 12 concrete, the required volume is $0.004 \times 12=0.048 \mathrm{~m}^{3}$. So that many needs based on the composition of the concrete mixture per fruit are listed in table 5.

Table 5. The composition of concrete mixtures $(\mathrm{kg})$ for 12 concrete beams.

\begin{tabular}{ccccccc}
\hline $\begin{array}{c}\text { Comparison of the } \\
\text { the composition of } \\
\text { the Concrete mixture }\end{array}$ & Cement & Sand & gravel & Styrofoam & Water & Mass (kg) \\
\hline $1: 5.0: 1.0: 0$ & 8,76 & 47,88 & 12,36 & 0 & 2,04 & 71,04 \\
$1: 4,25: 0,85: 0,90$ & 8,76 & 40,68 & 10,44 & 0,144 & 2,04 & 62,064 \\
$1: 3,25: 0,65: 2,10$ & 8,76 & 31,08 & 8,04 & 0,324 & 2,04 & 50,244 \\
$1: 2,50: 0,5: 3,00$ & 8,76 & 19,56 & 6,12 & 0,456 & 2,04 & 36,936 \\
\hline
\end{tabular}

For 12 pieces of concrete needed to be tested, the volume of constituent material is required = $0.048 \mathrm{~m} 3$ and the composition of the requirements is shown in table 4.10. To determine the needs of concrete constituent materials per piece of concrete made the concrete shape that we want, and has been done and made to the size of the building and composition with the data below: Dimensions of Concrete dimensions: $10 \times 20 \mathrm{~cm}$ for Cylinders with volume $\mathrm{V}=1 / 4 \pi$ $\mathrm{D} \wedge 2 \mathrm{t}=1570 \mathrm{~cm}^{3}$ is equivalent to $0.001570 \mathrm{~m}^{3}$. For the manufacture of 45 cylindrical concrete, the required volume is $0.001570 \times 45=0.07065 \mathrm{~m} 3$. So that many needs based on the composition of the concrete mixture per fruit are listed in table 6.

Table 6. Cylinder concrete composition $(\mathrm{kg})$

\begin{tabular}{ccccccc}
\hline $\begin{array}{c}\text { Comparison of the } \\
\text { composition of the } \\
\text { Concrete mixture }\end{array}$ & Cement & Sand & Gravel & Styrofoam & Water & $\begin{array}{c}\text { Concrete } \\
\text { mass }(\mathrm{kg})\end{array}$ \\
\hline $1: 5.0: 1.0: 0$ & 0,28 & 1,57 & 0,40 & 0 & 0,067 & 2,25 \\
$1: 4,25: 0,85: 0,90$ & 0,28 & 1,33 & 0,34 & 0,0045 & 0,067 & 2,02 \\
$1: 3,25: 0,65: 2,10$ & 0,28 & 1,02 & 0,26 & 0,0105 & 0,067 & 1,63 \\
$1: 2,50: 0,5: 3,00$ & 0,28 & 0,64 & 0,20 & 0,0150 & 0,067 & 1,20 \\
\hline
\end{tabular}


Table 7. Cylinder concrete composition $(\mathrm{kg})$ for 45 concrete

\begin{tabular}{ccccccc}
\hline $\begin{array}{c}\text { Comparison of the } \\
\text { composition of the } \\
\text { Concrete mixture }\end{array}$ & Cement & Sand & Gravel & Styrofoam & Water & $\begin{array}{c}\text { Concrete mass } \\
\text { (kg) }\end{array}$ \\
\hline $1: 5.0: 1.0: 0$ & 12,6 & 70,65 & 18,0 & 0 & 3,015 & 104,265 \\
$1: 4,25: 0,85: 0,90$ & 12,6 & 59,85 & 15,3 & 0,20 & 3,015 & 90,965 \\
$1: 3,25: 0,65: 2,10$ & 12,6 & 45,90 & 11,7 & 0,47 & 3,015 & 73,685 \\
$1: 2,50: 0,5: 3,00$ & 12,6 & 28,80 & 9,0 & 0,67 & 3.015 & 54,085 \\
\hline
\end{tabular}

Table 8. Average concrete unit weight test results

\begin{tabular}{ccccc}
\hline $\begin{array}{c}\text { Styrofoam } \\
\text { Volume }(\%)\end{array}$ & $\begin{array}{c}\text { Mass of Average Beam } \\
\text { Concrete Unit }(\mathrm{kg} / \mathrm{m} 3)\end{array}$ & $\begin{array}{c}\text { Average Cylinder } \\
\text { Concrete Unit mass } \\
(\mathrm{kg} / \mathrm{m} 3)\end{array}$ & \multicolumn{2}{c}{ Reduction (\%) } \\
Balok & Silinder \\
\hline 0 & 5,920 & 2,25 & 0 & \\
15 & 5,172 & 2,02 & 0,12 & 0,10 \\
35 & 4,187 & 1,63 & 0,29 & 0,27 \\
50 & 3,078 & 1,20 & 0,48 & 0,46 \\
\hline
\end{tabular}

\section{Compressive Strength of Concrete}

Testing the compressive strength of concrete using UTM machines with a capacity of 1000 KN. The results of the calculation of the average concrete strength can be seen in Table 9.

Table 9. Calculation results of concrete strength (MPa)

\begin{tabular}{ccc}
\hline $\begin{array}{c}\text { Styrofoam volume } \\
(\%)\end{array}$ & Test Age (Days) & $\begin{array}{c}\text { Average Concrete } \\
\text { Strength (MPa) }\end{array}$ \\
\hline \multirow{2}{*}{0} & 14 & 20,94 \\
& 21 & 24,25 \\
& 28 & 27,74 \\
\hline \multirow{2}{*}{15} & 14 & 12.69 \\
& 21 & 15.10 \\
& 28 & 17.76 \\
\hline \multirow{2}{*}{35} & 14 & 8.21 \\
& 21 & 11.03 \\
& 28 & 13.12 \\
\hline \multirow{2}{*}{50} & 14 & 4.75 \\
& 21 & 4.94 \\
\end{tabular}

The weight inspection of concrete units is carried out when the concrete is 28 days old.

\section{Morphological results from SEM}


From the morphological results of the SEM results from Styrofoam mixing of the supporting components of concrete sand and gravel, this material has an effect on the composition composed of the material as shown in the picture above. EDX results from the concrete constituent material show that Styrofoam which amounts to $50 \%$ of the overall concrete volume looks stiffer. [8], [9],[10]

Thus the results of 50\% styrofoam mixture showed that morphology from mixing concrete supporting groups and styrofoam was more dominant.

Thus a mixture of $355 \%$ styrofoam is seen that the composition of the mixture for $35 \%$ styrofoam is seen to occupy less quantity as seen by figure 4.3.

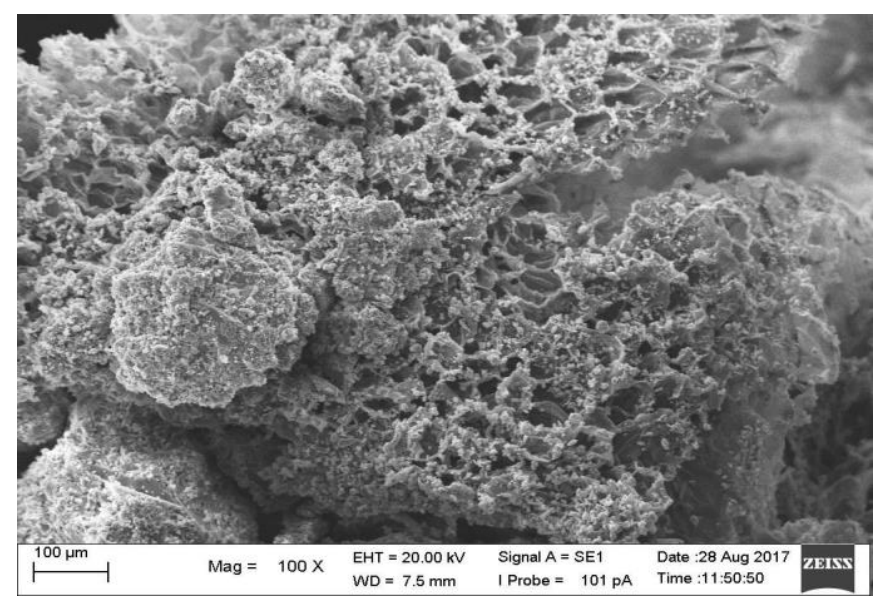

Fig 2. Mixing styrofoam with a composition of $50 \%$

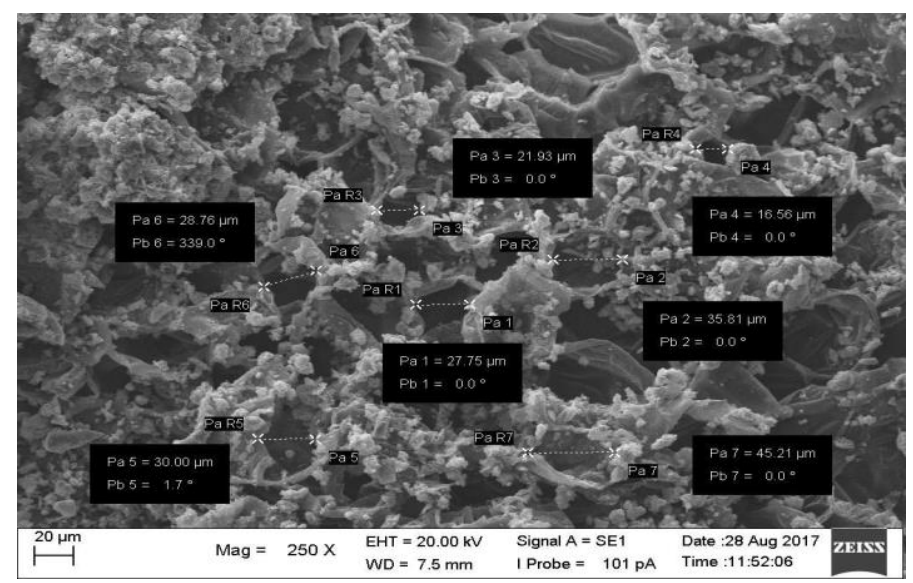

Fig 3 Styrofoam mixture with a composition of 35\% 


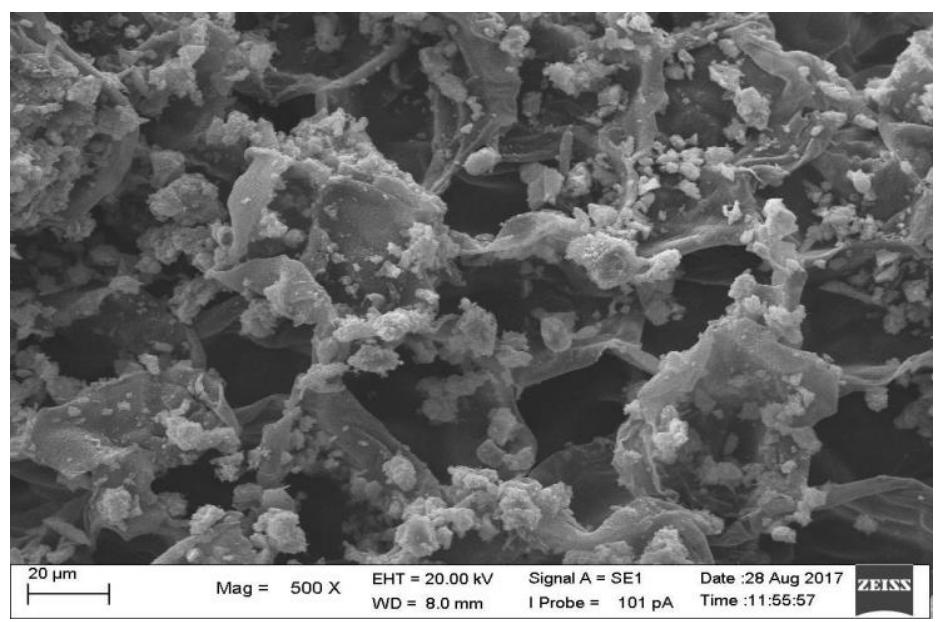

Fig 4. Styrofoam mixture with a composition of $15 \%$

Thus a mixture of $15 \%$ styrofoam is seen that the composition of the mixture for $15 \%$ styrofoam is seen to occupy less quantity as seen by Figure 4.4.

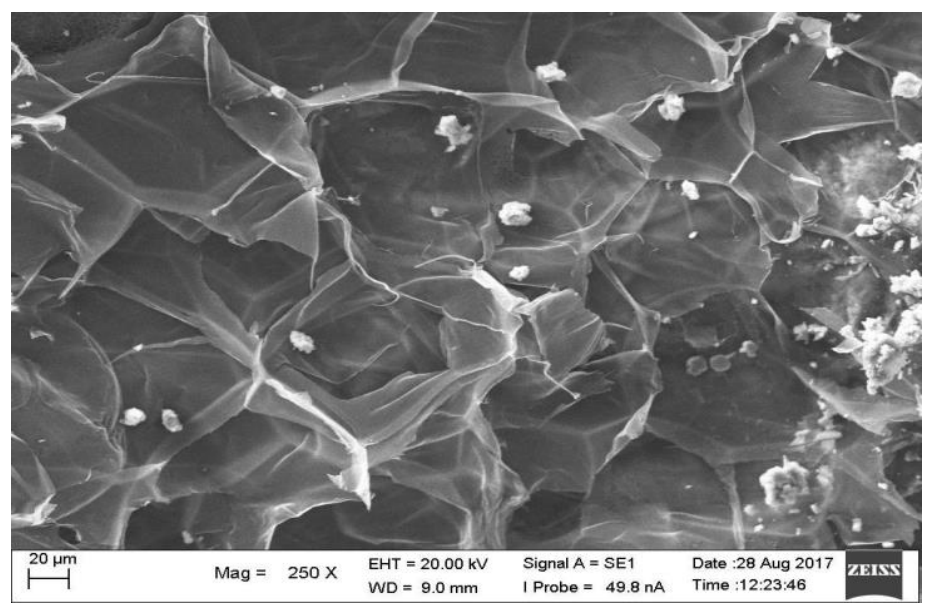

Fig 5. Styrofoam mixture with a composition of $0 \%$

From the results of SEM, the Styrofoam composition has not played a role in the constituent components of concrete, so there is no morphology of Styrofoam in Fig $\mathbf{5}$.

\section{Conclusions and recommendations}

\subsection{Conclusion}


The addition of $35 \%$ styrofoam from the volume of concrete can be categorized as lightweight concrete with a maximum weight range of $1900 \mathrm{~kg} / \mathrm{m} 3$. The compressive strength of concrete is influenced by the volume of styrofoam in the concrete mixture. Where the greater the volume of styrofoam, the lower the compressive strength produced. The compressive strength values with $0 \%, 15 \%, 35 \%$, and $50 \%$ styrofoam volume on average at 28 days were 27.74 MPa, 17.76 MPa, 13.12 MPa, and 5.26 MPa. From the results of the split tensile test, it was found that the greater the volume of styrofoam the lower the split tensile strength produced by the maximum reduction of normal concrete by $62.46 \%$ in the volume of $50 \%$ styrofoam. For flexural strength test, the percentage decrease in flexural strength at $15 \%, 35 \%$, and $50 \%$ of styrofoam volume increase on normal concrete blocks was $18.76 \%, 30.83 \%$, and $44.54 \%$ respectively. So that the greater the volume of styrofoam added to the concrete, the lower the value of the flexural strength produced. Morphology from styrofoam I concrete constituent material can be seen that styrofoam which amounts to $50 \%$ of the overall concrete volume looks stiffer. [10]

\section{Acknowledgments}

Experimental work carried out by civilian laboratories assisted by physics and civilian undergraduate students work together in this independent research 2017.

\section{References}

[1] T. Onet, "High performance concrete," Concrete, vol. 2, pp. 5107-5113, 2009.

[2] F. J. Vecchio, "Disturbed Stress Field Model for Reinforced Concrete: Formulation," J. Struct. Eng., vol. 126, no. 9, pp. 1070-1077, 2000.

[3] O. Korner, M. Andersen, and B. N. Jørgensen, "Development of future greenhouse climate control," Energy in Focus - From Kyoto to Copenhag, pp. 8-9, 2009.

[4] T. Griepentrog, "Buildings Made of...Styrofoam?,” Mother Earth News, 2008.

[5] A. P. Wibowo, "Water absorption of styrofoam concrete," ARPN J. Eng. Appl. Sci., vol. 12, no. 16, pp. 4782-4785, 2017.

[6] O. R. McIntire and R. N. Kennedy, "Styrofoam for Low Temperature Insulation," Chem. Eng. Prog., vol. 9, pp. 727-730, 1948.

[7] Hyder, domestic and international fate of end-of-life Tires - Final Report. Hyder Consulting Pty Ltd, 2012.

[8] Pacheco-Torgal, D. F., L. and Jalali, and S, "Properties and durability of concrete containing polymeric wastes (tire rubber and polyethylene terephthalate bottles): An overview", Construction and Building Materials," Constr. Build. Mater., vol. Vol. 30, pp. 714-724, 2012.

[9] Australia and Standards, "Structural design actions - wind actions," AS / NZS, vol. 2, p. $1170,2011$.

[10] Egerton and R. F., "Physical principles of electron microscopy: an introduction to TEM, SEM, and AEM," p. 202, 2005. 
